\title{
Resilient Affordable Housing Strategies: A methodological approach to analyzing the impacts of Barcelona's inclusionary housing policy on affordability in gentrifying neighborhoods
}

\author{
Walker Toma ${ }^{1, *}$ \\ ${ }^{1}$ Univsersitat Internacional de Catalunya / Carrer de la Immaculada, 22, 08017 Barcelona, Spain \\ E-Mail: walkertoma@gmail.com
}

Tel.: +34 653788727

\begin{abstract}
Housing unaffordability, gentrification and related residential displacement and exclusion are well-documented stresses that limit the resilience of a given urban place. The Barcelona City Council is dedicated to alleviating these stresses through a comprehensive strategy comprised of a variety of policy initiatives addressing housing affordability. As part of this broader strategy, the City Council has proposed a citywide inclusionary housing measure requiring 30 percent of all newly developed or significantly rehabilitated housing units to be dedicated as protected public housing. This paper fits within a larger research effort seeking to better understand the proposed initiative's impacts related to its purported goal of public housing production as well as broader implications on the housing market. To do so, this paper provides a methodological framework for assessing these policy implications using neighborhood-specific economic feasibility modelling. Through the examination of inclusionary policies in comparable cities in the U.S. and Western Europe, this paper will form a basis from which to critique the proposed policy due to its inflexibility and lack of neighborhood-specific adaptability while maintaining that a well-designed inclusionary policy can generate significant public benefits to the City of Barcelona.
\end{abstract}

Keywords: Inclusionary housing, economic feasibility, Barcelona, affordable housing, urban resilience.

\section{Introduction}

The City of Barcelona has embraced an approach to improving housing affordability driven by a firm belief in the 'right to the city' while maintaining an engagement with the realities imposed by existing economic and policy structures. One example of this approach is the expected adoption of a citywide inclusionary housing policy (30\% of all units in new development or significant rehabilitation is to be dedicated at social rent)(Ajuntamiento de Barcelona 2018), which seeks to leverage private 
sector investment as a vehicle for generating affordable housing units in communities particularly affected by gentrification and displacement pressures.

While there exists a limited body of research on the impacts of inclusionary policies on housing markets, a review of available literature suggest that the efficacy of such policies is closely related to their flexibility (i.e. contextual adaptability by neighborhood, development type or market activity) (Schuetz et al. 2009), (Non-Profit Housing Association of Northern California 2007) and regional scope (i.e. should similar policies be enacted in neighboring cities, local impacts on the real estate market are expected to be less severe as developers would face similar policy environments in nearby municipalities) (Hughen and Read 2013). The current measure, that is expected to gain full approval by the end of 2018, is not anticipated to include significant implementation flexibility, though a number of cities within the region, along with the Generalitat de Catalunya (Catalonia provincial government), have expressed interest in implementing a more far-reaching inclusionary policy (Nadeu 2018).

This paper provides a methodological framework for assessing the efficacy of Barcelona's proposed citywide inclusionary housing policy from an economic feasibility perspective to evaluate whether the policy will generate intended outcomes at the urban scale. Intended outcomes are understood in the context of this research as increasing the affordable housing stock without indirectly increasing housing prices in the private market through limiting supply. As part of this effort, this paper first provides a justification for the creation of an inclusionary policy in Barcelona through a documentation of the stresses affecting affordability and a demonstration that such a policy may help alleviate these stresses and in turn build resilience.

Secondly, this paper provides a brief contextual examination of Barcelona Mayor, Ada Colau's, current housing affordability initiatives, how the inclusionary policy fits within its greater strategy, and the potential public benefits a well-designed inclusionary policy could generate, furthering efforts to create a more resilient Barcelona. Thirdly, through a review of existing inclusionary policies in other major cities in Western Europe and the United States, this paper seeks to both further justify the pursuit of inclusionary policies in Barcelona and provide a basis for critiquing the process through which the Ajuntament (City Council) developed the initiative and the contents of the initiative itself. In particular, this paper seeks to provide a basis for critiquing the policy as initially designed due to its inflexibility, lack of neighborhood-specific adaptability, and questioning its expected adoption with limited in-depth analysis on its potential economic impacts.

Once a basis has been established both to support the implementation of a well-crafted inclusionary policy in Barcelona and yet critique the composition of the currently proposed policy, I will then argue for the need to both evaluate the proposed policy at the neighborhood scale and to ensure it is properly and consistently calibrated to effectively address the affordability issues for which it is designed. As part of this effort, this paper will present a methodology for evaluating the proposed inclusionary policy in Barcelona at the neighborhood scale through the selection of specific areas on which additional research will focus.

Lastly, this paper illustrates how economic feasibility analyses can inform projections of development activity (and therefore the generation of affordable units), outlines how further research will be conducted in this regard, and demonstrates ways in which the proposed policy may be calibrated to better achieve its intended goals at both the neighborhood and urban scales. Therefore, an overview of the methodological approach for developing economic feasibility modeling will be provided herein.

\section{Housing affordability stresses in Barcelona limit urban resilience}

Housing affordability remains a pressing priority in Barcelona. The discussion of how housing policy can better serve the City's inhabitants was the central campaign theme of the current Mayor and continues to drive major policy initiatives impacting spatial, social, economic and political dynamics in Barcelona. Current Housing Manager, Javier Burrón, describes the state of housing in Barcelona as a "housing emergency... [comprised of] evictions, [the] inability of broad layers of society to pay rent based on their salaries, displacement of low- and middle-income long-term residents from neighbourhoods by higher-income outsiders... [along with the] growth of social housing 
exclusion...[and] the lack of a diversified and sustainable housing model for a society of pensioners." Due to this state of housing emergency, Mr. Burrón has helped develop the formation and implementation of new public housing policies at the local level (Montaner et al. 2016). Existing and proposed policy initiatives are diverse in approach, robust in scope, and largely focused on directly or indirectly increasing the available number of affordable units in the city, be it through the private market or through increasing the public housing stock.

Yet despite the prioritization and concerted efforts, the City Council faces an uphill battle in delivering on its housing policy goals. Although Article 73 of Act 18/2007, or the Right to Housing Law of 2007, committed to a increasing the affordable housing stock to 15 percent of total housing by 2027, as of 2014, this figure remained below 1.5 percent. The Right to Housing Plan (2016-2025), which was approved in 2017, acknowledges this insufficiency yet restates a commitment to meet the 2027 goal and refers readers to the 77 percent yearly increase in public spending on housing between 2014 and 2015. However, based on current projections, and even greater funding commitment will be required to meet the 2027 goal (Right to Housing Plan 2017).

The Right to Housing Plan (2016-2025), along with a number of official documents, studies, and press releases, discuses some of the leading characteristics affecting the current state of housing Barcelona including pressures affecting affordability, trends indicating the continued gentrification of specific areas of the city and the exacerbation of certain factors generating displacement and housing exclusion, as well as efforts the current administration has undertaken to address housing affordability in Barcelona.

This research positions itself to assess a specific policy initiative (inclusionary housing) based on a belief, which is shared by the current city government (Gabàs 2018), (Pagani 2018), that an alleviation of key stresses negatively impacting the affordability of, and access to, housing for all city inhabitants, will help to create a more resilient city. Through an ongoing partnership between the City Council of Barcelona, and in particular the Resilience Department, and UN-Habitat's City Resilience Profiling Programme (CRPP), a series of key stresses have been studied to varying degrees in an effort to better prioritize and refine policy initiatives addressing housing affordability in the future.

Identified stresses affecting housing affordability and therefore resilience in the City of Barcelona include, but are not limited to, relocation and displacement pressures generated by economic insecurity, displacement pressures stemming from conversion of residential units to touristic apartments, foreign investment in the housing market increasing real estate demand and therefore housing prices, stagnation of real wages relative to the growth in housing costs, spatial and policy context limiting new production of housing in the city and therefore limiting new supply, continued speculation within the real estate industry that serves both to artificially constrain supply and increase land values, among others.

While an inclusionary policy does not possess the ability to mitigate all of these key stresses, a welldesigned policy can provide a mechanism for effectively mitigating gentrification-inducing residential displacement and exclusion in a targeted manner. Such mitigation occurs as inclusionary policies harness gentrification pressures (or investment in areas where developers have identified profit potential) to finance the creation of new affordable units in sitio. In doing so, a well-designed inclusionary policy should be understood as both generating public benefits and building resilience for the City of Barcelona.

\section{Overview of current administrative initiatives in Barcelona addressing housing affordability}

As noted in the previous chapter, housing affordability remains a priority for the current Barcelona City Council. The inclusionary housing policy central to this research fits within a broad strategic effort at the city scale to enable a 'right to the city' for inhabitants, or more precisely a 'right to housing'. One of the strategic lines identified in the Right to Housing Plan (2016-2025) is increasing the stock of affordable housing. The four pillars that comprise this effort are 1) to increasing the current public housing stock, 2) extending the coverage of, and improve access to, rent subsidies, 3) the conversion of private housing units into affordable housing, and 4) boosting the social market, which refers to community-based efforts that go beyond housing itself to ensure socio- 
economic support is provided more broadly to the citizenry. Research efforts addressed in this report focusing on the potential adoption of an inclusionary housing policy primarily falls within the first of these four pillars: the expansion of public housing.

The context within which the City Council's strategy for expanding public housing stocks includes a history of very limited investment by the public sector and a focus on using public housing as a wealth building mechanism over the past few decades (Montaner et al. 2016). The combination of housing policies prioritizing private ownership (e.g. subsidizing mortgages) and the creation of public housing that was not intended to be permanent (i.e. after a predetermined period, the public housing occupants could often sell units on the private market) has meant that Barcelona, and Spain more broadly, have some of the lowest levels of public housing in the European Union (Ponce 2004).

Given the existing deficit of public housing in Barcelona, which has been shown to be directly related to housing unaffordability in recent research (Angel and Kallergis 2016), the City Council has initiated, expanded upon, strengthened, and altered a variety of approaches to both expanding the physical stock of public units as well as increasing access to affordable housing more generally. The current approach includes, but is not limited to, efforts to acquire new housing units directly from the private market; regulate pricing of existing rental units (i.e. 'rent control'); the development of new affordable properties through public-private entities; cohousing initiatives; direct rent subsidies (i.e. public assistance in the private market); adaptive reuse of existing public facilities into housing; adaptive reuse of vacant, bank-owned homes for public housing; and a citywide inclusionary housing policy (Ajuntament de Barcelona 2017), (Montaner et al. 2016).

Furthermore, prioritization of housing affordability has not been limited to political rhetoric. The overall budget to support the housing affordability goals identified in the Right to Housing Plan (20162025) was increased by 64 million euros in a joint session of the Consorci de l'Habitatge de Barcelona (Barcelona Housing Consortium), raising the financial contributions allocated to housing policies to approximately 647 million euros. The distribution of these funds, the sources of which are derived from both the Ajuntament (City Council) (81 percent of the total) and the Generalitat de Catalunya (provincial government of Catalonia) (19 percent), is as follows (Ajuntament 2018):

Figure 1. (a) Distribution of funds allocated towards Barcelona housing policies 2018-2023
\begin{tabular}{|l|c|c|}
\hline Housing Approach & $\begin{array}{c}\text { Budget (millions } \\
\text { of euros) }\end{array}$ & $\begin{array}{c}\text { Estimated units / } \\
\text { users * }\end{array}$ \\
\hline Promotion of new construction & 337 & 4,644 \\
\hline Direct acquisition of housing & 105 & 1,064 \\
\hline Conversion of private flats into public housing & 25 & 505 \\
\hline Direct rent subsidies & 79 & $40,000^{*}$ \\
\hline Renovation subsidies & 101 & $40,000^{*}$ \\
\hline
\end{tabular}

(b) Barcelona City Council

Inclusionary housing is an attractive policy option for local governments as it does not require direct public spending, but rather leverages private sector development activity to increase public housing stock. As illustrated in Figure 1, the Barcelona City Council estimates that 337 million euros will be used to produce 4,644 new public housing units and 105 million euros to acquire 1,064 units, resulting in a per unit costs of 72,000 euros and 99,000 euros, respectively. For comparison, if we assume the 300 to 400 annual unit production projections concluded by the City Council stemming from the proposed inclusionary program (Jorro 2018), over an equivalent period of five years (based on the 2018-2023 funding allocation shown in Figure 1), we should expect the generation of between 1,500 and 2,000 public housing units. Applying per unit costs for direct development and acquisition, the estimated cost of these units would be between 108 and 198 million euros. ${ }^{1}$

Therefore, an inclusionary policy has the potential of delivering enormous public benefits without requiring direct public expenditures. The policy in Barcelona should thus be understood as a

\footnotetext{
${ }^{1}$ Calculation provides a range assuming 1,500 units would be produced at 72,000 euros per unit and 2,000 units at 99,000 euros per unit.
} 
complimentary approach to other efforts at increasing affordability within the city and one that, if calibrated effectively, can provide the City Council with a fiscally efficient tool for increasing housing affordability and therefore resilience at both the neighborhood and urban scale.

\section{Comparison of existing inclusionary housing policies in the United States and Western Europe}

Inclusionary zoning can be defined as a form of land-use policy that enables some lower- and moderate-income households to live in middle-and upper-income communities either by mandating or encouraging real estate developers to incorporate a proportion of units that are sold or rented at belowmarket prices in exchange for development rights or zoning variances (Schwartz et al. 2012).

While inclusionary housing policies have garnered limited academic analysis regarding effects on housing prices, existing literature, which primarily refers to cases in the United States, largely indicates that the impacts of inclusionary policies on housing prices are relatively limited (California Coalition for Rural Housing 2003). This limited pricing impact is due to housing developers' unwillingness to pass along increased development costs to consumers for fear of a competitive disadvantage in the market (i.e. consumers in competitive development markets force developers to accept lower profit margins, therefore maintaining prices at pre-policy levels) (Schuetz et al. 2009). However, in areas with heightened demand (i.e. low vacancy, rapidly escalating land costs, etc.), higher housing prices may occur following the adoption of inclusionary policies as consumers are willing to 'absorb' the higher costs, therefore paying a premium to live in a specific location (Padilla 1995), (Knaap, Bento and Lowe 2008).

This chapter presents a brief overview of established inclusionary housing policies in selected major cities in Western Europe and the United States. The four cities included in this brief analysis possess economic similarities to Barcelona such as being competitive housing markets with relatively high land values, low vacancies, and persistent development activity, both from new development and rehabilitation projects. While it should be noted that all urban environments feature unique dynamics within the housing sector, the presentation of these selected cases is intended to illustrate some of the existing policy initiatives and, if available, synopses of these policies quantitative impacts on the housing market.

\subsection{San Francisco, California, United States}

Initially established in 1992, San Francisco's Inclusionary Housing Ordinance requires that all market-rate projects of 10 units or more contribute to the City's affordable housing stock. There are three ways for a project to do this: 1) build Below-Market-Rate (BMR) units on-site equal to 12 percent of the total project units, 2) build 20 percent of the total project units as BMR off-site on a separate parcel of land or, 3) pay a fee to the City equivalent to 20 percent BMR (calculated based on a set fee that is updated every year intended to estimate the cost of constructing a BMR unit) to the Mayor's Office of Housing $(\mathrm{MOH}){ }^{2}$

The majority of developers in recent years have opted to provide off-site BMR units or pay the fee to the City (options 2 and 3 defined above), the result of which is that either the responsibility of additional BMR unit development is shifted to the $\mathrm{City}^{3}$ or the BMR units are not necessarily located in the same neighborhood as the associated market-rate development, therefore limited the policy's efficacy of mitigating residential exclusion. One rationale for this trend is the rate with which land values change in a city like San Francisco, wherein fee levels that are determined on an annual basis may be significantly outdated (i.e. too low) and therefore a far more attractive economically.

No definitive study has been completed illustrating whether or not the inclusionary policy has had observable impacts on housing prices or overall supply in San Francisco, though a literature review

\footnotetext{
${ }^{2}$ Note that these percentages are slightly higher in certain parts of the Eastern Neighborhoods Plan (ENP), which is a special planning area with a zoning ordinance that supersedes the citywide policy.

${ }^{3}$ Fees collected as a part of the described mechanism flow to the Housing Trust Fund, which then funds affordable housing development projects pursued by the City and County of San Francisco.
} 
finds a greater proportion of academic discourse finding little to no effect (Schuetz et al. 2009), (Hollingshead 2015).

\subsection{Boston, Massachusetts, United States}

Originally established in 2000, and significantly revised in 2015, Boston's Inclusionary Development Policy ("IDP") applies to all residential projects of 10 or more units that meet certain criteria. Projects exempt from the policy include those which include affordable housing exceeding a certain threshold, are characterized as dormitory housing (e.g. housing for university students), those projects which were approved prior to official establishment of the policy, and projects that are exempt due to other specified sections of the Zoning Code. Projects that do not qualify for an exemption are required to dedicate 13 percent of the total number of units on-site or 18 percent off-site. The IDP is enforced differently across three established "zones" in the city in an attempt to reflect varying economic realities. Projects may also contribute per-unit fees, which vary depending on the Zone wherein the project is located (e.g. in Zone A, projects are required to contribute payments for 18 percent of total project units at a fee of $\$ 380,000$ per unit. In Zone $C$, a payment of $\$ 200,000$ per unit is levied on 15 percent of total units) (BPDA 2015).

In 2016, the IDP was revised further to allow more flexibility for developers in an effort to produce more affordable units in more neighborhoods throughout the city (BPDA 2015). Key revisions included the adoption of density bonuses, which allows developers to build at greater densities than allowed under the existing zoning in return for providing a greater number of affordable units than would otherwise be required under the IDP.

The effects on housing prices in Boston due to the IDP is, similar to San Francisco, a debatable issue, though most comprehensive reviews have not found significant impacts on supply, rental rates, or land values (Schuetz et al. 2009).

\subsection{Paris, Ille de France, France}

In France, a national policy called the Solidarity and Urban Renewal Law (SRU) establishes that every municipality with more than 3,500 inhabitants (or more than 1,500 in municipalities located in Ille de France, or the province surrounding Paris) must have a social housing share of at least 20 percent. In addition to the national policy (Pittini and Laino 2011). For the national policy, municipalities that do not fulfill their obligation of providing 20 percent social housing are subject to a tax. However, many wealthier municipalities choose to pay the annual tax as opposed to meeting the requirement fearing negative reputational impacts stemming from the arrival of a lower income population (Republique Francaise 2014), (Lazarovic 2010).

In 2004, Paris adopted a provision which required a 25 percent social housing set aside in all new development located in arrondissements (neighborhoods) where the current percentage of social housing was less than 20 percent (Calavita and Mallach 2010), (Rose et al. 2012). The policy was designed in direct response to the perception of the effects of affordable housing efforts in the City of London, which we viewed by Paris housing advocates at the time as perpetuating segregation. In practice, the policy has been challenging in its implementation due to the complex and cumbersome housing regulatory system (Calavita and Mallach 2010), leading to a far more politicized, ad-hoc process for securing development approvals and thus often circumventing the original intention of the policy.

The effects of the Parisian inclusionary requirements have generally been well-received in that the policy has generated significant new social housing, much of which has been located in higher income areas (Lazarovic 2010). Limited study or data on the impacts of the inclusionary policy in Paris on housing prices overall is available.

\subsection{London, Greater London, England}

The 1990 Town and Country Planning Act, and specifically Section 106 (S106) of the Act (known as S106 agreements), allows local authorities the power to require new development to contribute 
affordable housing units or fees in return for development rights (Monk 2010). On the national level, S106 agreements have contributed to the vast majority of all affordable housing development since 2000 (Morrison and Burgess 2013), with the greater London area and southern England involved in far more agreements than northern counties. Therefore, inclusionary policies vary between municipalities and are subject, in certain circumstances, to ad hoc negotiations on a case-by-case basis.

In 2017, London Mayor Sadiq Khan proposed to streamline the development process by allowing any new residential project to bypass the, often cumbersome, application process if developers meet a strict 35 percent minimum affordable housing inclusion and do not require any public funding. For projects requiring public funding, a 50 percent minimum is imposed for the fast-track process. The new provision was designed to address the increasingly expensive housing market in London, while median incomes remain relatively flat post-financial crises. The new streamline application process, which forms a central characteristic of Khan's Homes for Londoners policy initiative, forms part of a larger strategy to address housing affordability in the city (London City Hall 2017).

Existing off-site and cash in lieu agreements remain viable with the adopted of the new policy, though no equivalent fast-track option is available in an attempt to disincentivize such options. Also maintained is a provision wherein income limits for affordable housing is determined by each neighborhood to ensure affordability levels remain sensitive to income levels and real estate valuation differences around the city.

Research has shown that inclusionary policies in England have not deterred development activity due to the institutionalized nature of the policies in the real estate community (Monk 2010). However, there is general agreement that the imposition of a 35 or 50 percent inclusionary requirement likely does increase housing prices in London (Morrison and Burgess 2013), although academic quantitative analysis of recent policy changes is not currently available.

\subsection{Barcelona, Catalonia, Spain}

The City Council of Barcelona has proposed a citywide inclusionary housing policy, which if adopted in its current incarnation, would mandate all new housing development or significant rehabilitation (defined as if construction costs exceed 50 percent of the value of the building) to provide 30 percent of the total units as officially protected units (viviendas de protección official (VPO)). The proposed policy would require two modifications of the Plan General Metropolitano (PGM) and apply to every district in Barcelona. The proposal appears to have sufficient support to pass unamended by the end of 2018 (Romano Córdoba 2018).

The Generalitat de Catalunya, in addition to numerous nearby cities, have expressed interest in adopted similar measures in order to both present a consistent policy framework in the metropolitan area as well as increase the development of affordable housing units (Romano Córdoba 2018), (Jorro 2018).

The reaction from the development community to the proposal has been claims that the measure will stop housing development, limit rehabilitation work on older buildings, and increase prices citywide due to constrained supply and the increased cost of development (Nadeu 2018), (Jorro 2018). While such reactions are commonplace in discussions of inclusionary housing, the level of outrage of cited reactions from the building community may stem from a feeling of exclusion from the development of policy which will affect them significantly (Romano Córdoba 2018).

The City Council maintains that the policy will effectively achieve its desired results and has citied projections that the policy will produce between 300 and 400 public housing units per year (Jorro 2018). While the basis for this calculation have not yet been made public on accessible forums such as BCNROC (Repositori Obert de Coneixement de lÁjuntament de Barcelona), given development activity over the past three years, which is presented in greater detail in Chapter 6, the 300 to 400 -unit figure would align with an assumption of a continuation of current development trends. In other words, it appears the City Council has assumed the policy will have little discernable impact on the level of development activity in the city.

\subsection{Case Study Comparison}


While further analysis is required to understand the nuances of how the selected inclusionary policies were initially developed and, in certain cases, subsequently revised, general takeaways include 1) the policies have become more flexible and neighborhood-specific over time; 2) the policies are intended to provide a fiscally unencumbering development mechanism that generates affordable housing in higher income areas where housing is not easily accessible; 3 ) in the U.S. cases, incentives such as density bonuses were implemented to encourage development in areas of the city deemed priorities; and 4) significant increases in housing prices as a direct result of inclusionary policies were not identified.

In comparison to these selected cases, the proposed Barcelona policy is more ambitious in its proportion of affordable units mandated (aside from London) and, in its current incarnation, does not provide incentives to try and offset the increased development costs. Lastly, the Barcelona policy does not attempt to calibrate the inclusionary obligation based on location, opting instead to apply a blanket policy at the city scale.

\section{Research Methods and Design}

The methods that will be utilized in this research include a review of quantitative and qualitative data derived from previously developed research conducted by the City Resilience Profiling Programme (CRPP), public sources, and through interviews with policymakers and the development community. The data stemming from previous CRPP analysis has allowed for a justification of neighborhood selection for which further analysis and development permitting projections will be conducted. The criteria for neighborhood selection are discussed in the following chapter (6).

Additional data will form the basis of the economic feasibility models, which will be provide an assessment of the impacts of the adopted inclusionary policy on both new construction and rehabilitation projects in the selected neighborhoods. These impacts can then inform projections of development activity and help determine the efficacy of the inclusionary policy in achieving its desired outcomes (i.e. producing affordable housing units without negatively impacting affordability in the housing market overall). An overview of how the economic feasibility models will be constructed and utilized is presented in chapter 7 .

\section{Neighborhood-scale approach to inclusionary housing and selection methodology and results}

In order to effectively calibrate an inclusionary housing policy in a dynamic urban housing market, such as Barcelona, it is necessary to recognize the variances within neighborhoods and understand the context-specific policy impacts. This is because current development activity is not evenly distributed throughout Barcelona neighborhoods but rather is determined by a number of economic considerations including land values, construction costs, spatial and planning considerations including zoning restrictions, location of key infrastructure and amenities (e.g. parks, transit, cultural and commercial amenities), and available development sites, among a myriad of additional contextual factors that influence the feasibility of a given project. As has been documented through research of existing inclusionary policies and demonstrated in revisions of existing policies in direct recognition of unequal development environments ${ }^{4}$, an inclusionary policy calibrated to respond to structural economic variation between neighborhoods is likely better equipped to achieve its stated policy goals of improving affordability in the city (Calavita and Mallach 2010).

Additionally, with recognition of the importance of assessing inclusionary policy impacts at the neighborhood level but given the scale of development activity in Barcelona and the complexity required to construct neighborhood-specific feasibility models, the scope envisioned as a part of this initial research is restricted to two neighborhoods or Districts (out of a total of 10). Perhaps future research will attempt a more ambitious research scope so that coverage of all 10 official Barcelona Districts could be conducted.

This chapter presents criteria for neighborhood selection in which to measure the anticipated impacts of the adopted inclusionary measure. These criteria were selected in order to 1) focus on

\footnotetext{
${ }^{4}$ See revisions and current characteristics of inclusionary policies in both Boston and Paris.
} 
neighborhoods with significant gentrification and related displacement pressures and 2) ensure there is currently sufficient development activity to adequately project effects on permitting and/or unit development and evaluate whether the adopted inclusionary policy will have negative impacts on new housing delivery (i.e. supply).

The first goal of the criteria will be met using neighborhood measures of rent-to-income ratios. This indicator provides a simplistic evaluation of housing cost burden, a measure shown in repeated studies to predict displacement (Hodge 1981) and provides insight into other fundamental drivers of displacement and housing exclusion for vulnerable groups (Schill and Nathan 1983), (Atkinson 2004). Rental increases, income decreases, or a combination of these two trends which increases the rental burden of household budgets, is a strong indicator of displacement pressures and housing vulnerability (Ellen and O'Regan, 2010), (Walks and Maaranean 2008), (Mallach 2008).

This research recognizes the charged meaning associated with gentrification as well as the word's varied definitions. For the purposes of this paper and this line of research, gentrification is understood as a process wherein increased investment trends in the housing sector in a specific area result in increased property values and rents, which in turn displaces existing residents and excludes lower income inhabitants from housing in that area. This general definition is well aligned with the way in which housing affordability priorities are discussed in Barcelona's political discourse and publications outlining policy goals.

\subsection{Rent to Income Ratio by District}

As shown in Figure 2, rent to income ratios in Barcelona vary significantly by District from a low of 20 percent in Sarrià-Sant Gervasi to a high of 35 percent in Nou Barris. Six of the ten districts which exhibit above average rent-to-income ratios are highlighted in the table, indicating a heightened pressure for displacement, and therefore increased vulnerability to housing exclusion. These six districts include Ciutat Vella, Sants-Montjuïc, Horta-Guimardó, Nou Barris, Sant Andreu and Sant Martí.

Figure 2. (a) Rent to Income Ratio by District, City of Barcelona

\begin{tabular}{|l|l|l|l|l|}
\hline Household Income Variation by District & \multicolumn{2}{|l|}{ Average Rent per District } \\
\hline District & $\begin{array}{l}\text { HH Income } \\
\text { (Euros) }\end{array}$ & \% City Avg. & $\begin{array}{l}\text { Average Rent } \\
\text { (Annual) }\end{array}$ & $\begin{array}{l}\text { Rent to Income } \\
\text { Ratio }\end{array}$ \\
\hline Barcelona & 32,138 & 100.0 & 8,258 & $26 \%$ \\
\hline Ciutat Vella & 27,478 & 85.5 & 7,669 & $28 \%$ \\
\hline Eixample & 37,215 & 115.8 & 9,323 & $25 \%$ \\
\hline Sants-Montjuïc & 24,360 & 75.8 & 7,181 & $29 \%$ \\
\hline Les Corts & 44,896 & 139.7 & 10,236 & $23 \%$ \\
\hline Sarrià-Sant Gervasi & 59,230 & 184.3 & 11,736 & $20 \%$ \\
\hline Gràcia & 34,869 & 108.5 & 8,087 & $23 \%$ \\
\hline Horta-Guinardó & 24,971 & 77.7 & 6,766 & $27 \%$ \\
\hline Nou Barris & 17,258 & 53.7 & 5,992 & $35 \%$ \\
\hline Sant Andreu & 23,460 & 73 & 6,902 & $29 \%$ \\
\hline Sant Martí & 27,510 & 85.6 & 7,690 & $28 \%$ \\
\hline
\end{tabular}

(b) Data publicly available courtesy of the City of Barcelona; data synthesis courtesy of UNHabitat's City Resilience Profiling Programme (Pagani 2018)

\subsection{Development Activity Citywide and by District}

While a rent-to-income ratio may be well-suited to provide an indication of areas vulnerable to exclusion and other affordability-related issues, given the market-derived mechanism required from an inclusionary housing policy, in order to effectively evaluate the proposed measure, neighborhood selection must also take into account development activity. Figure 3 shows citywide development activity in Barcelona over the past seven years. After exhibiting very limited new housing starts in the 
years immediately following the global financial crises, development activity has increased to an average of over 1,300 units in recent years.

Figure 3. (a) Housing Units Constructed per Year, City of Barcelona

\begin{tabular}{|l|l|l|l|}
\hline Year & Housing Starts & Completed Units & Total Units \\
\hline 2011 & 1,073 & 1,839 & Not Available \\
\hline 2012 & 493 & 1,077 & Not Available \\
\hline 2013 & 697 & 666 & Not Available \\
\hline 2014 & 752 & 555 & 831,748 \\
\hline 2015 & 1,408 & 836 & 832,584 \\
\hline 2016 & 1,233 & 1,291 & Not Available \\
\hline 2017 & 1,373 & 1,039 & Not Available \\
\hline
\end{tabular}

(b) Data publicly available courtesy of the Barcelona City Council; data synthesis courtesy of UN-Habitat's City Resilience Profiling Programme (Pagani 2018)

In order to understand how development activity is distributed across districts, the three most recent years of data showing housing starts per 1,000 inhabitants was collected. A simple average was then calculated to provide a proxy for district-level development activity relative to population. Finally, as this research is concerned with development trends both relative to population as well as in an absolute sense, an estimated average number of housing starts per district per year was extrapolated using 2016 district level population data.

Figure 4. (a) Estimated Average Housing Starts per District ${ }^{5}$

\begin{tabular}{|c|c|c|c|c|c|}
\hline \multirow[t]{2}{*}{ District } & \multicolumn{4}{|c|}{ Housing Starts per 1,000 Inhabitants } & \multirow{2}{*}{$\begin{array}{c}\text { Est. Avg. Housing } \\
\text { Starts 2015- } \\
\text { 2017(c) }\end{array}$} \\
\hline & 2015 & 2016 & 2017 & $\begin{array}{l}\text { Avg. 2015- } \\
2017\end{array}$ & \\
\hline Barcelona & .88 & .77 & .84 & .83 & 1335 \\
\hline Ciutat Vella & .04 & .47 & .10 & .20 & 21 \\
\hline Eixample & 1.06 & .69 & .67 & .81 & 215 \\
\hline $\begin{array}{l}\text { Sants- } \\
\text { Montjuïc }\end{array}$ & 1.09 & 1.23 & 2.11 & 1.48 & 269 \\
\hline Les Corts & .27 & 1.34 & 1.74 & 1.12 & 92 \\
\hline $\begin{array}{l}\text { Sarrià-Sant } \\
\text { Gervasi }\end{array}$ & .54 & .57 & .31 & .47 & 71 \\
\hline Gràcia & .57 & .25 & .58 & .47 & 57 \\
\hline $\begin{array}{l}\text { Horta- } \\
\text { Guinardó }\end{array}$ & .43 & .46 & .60 & .50 & 84 \\
\hline Nou Barris & .76 & .48 & .22 & .49 & 81 \\
\hline
\end{tabular}

\footnotetext{
${ }^{5}$ Note that housing start estimates are calculated using a simple average across three years of extracted data and applied to 2016 population figures by District. Therefore, discrepancy with official citywide housing start data from Figure 2 exist. This table is intended not to provide definitive statistics but rather illustrate trends from which neighborhood selection can be based.
} 


\begin{tabular}{|c|c|c|c|c|c|}
\hline Sant Andreu & 1.94 & .70 & .49 & 1.04 & 154 \\
\hline Sant Martí & 1.17 & 1.28 & 2.62 & 1.69 & 398 \\
\hline
\end{tabular}

(b) Data publicly available courtesy of the Barcelona City Council and the L'Observatori Metropolità de l'Habitatge de Barcelona

As Figure 4 demonstrates, four of the ten districts have experienced above average development activity as measured by exhibiting a housing starts per 1,000 inhabitants ratio higher than the citywide figure (.83). These four districts include Sants-Montjuïc, Les Corts, Sant Andreu, and Sant Martí. However, regarding absolute development activity figures, Les Corts is replaced by Eixample. The three districts which exhibit both high relative and absolute development activity statistics include: Sants-Montjuïc, Sant Andreu, and Sant Martí, with Sants-Montjuïc and Sant Martí demonstrating higher metrics in both measures.

If we combine these findings from the rent-to-income indicator of Figure 2, we find that SantsMontjuïc and Sant Martí also meet the criteria of exhibiting higher rent-to-income ratios than the city average. Therefore, these two districts meet the developed selection criteria and will be used to analyze the proposed inclusionary housing measure using financial feasibility modelling. The following chapter provides an overview of the methodology that will be used to complete this assessment.

\section{Methodological overview of feasibility analysis structure and description of expected outcomes}

Financial feasibility analyses are often used to test proposed policy changes affecting the housing market to better understand how the private market may respond to newly imposed incentives or deterrents. In the case of inclusionary housing policies, and the Barcelona proposal in particular, by requiring new development and significant rehabilitation projects to set aside 30 percent of housing units at protected social rents, the development economics of projects will be altered considerably. In other words, this set aside can be understood as an added development cost, not unlike construction costs.

Through financial feasibility modelling, the policy's potential impacts on development can be measured through an understanding of whether current development economics can absorb this added cost. If a generic neighborhood-specific development model demonstrates that even with this added cost, acceptable profit margins or "hurdle rates" can be achieved, then we can expect a continuation of similar development patterns in the neighborhoods assessed and therefore generation of public housing units in line with the City Council projections as a part of the inclusionary mechanism. Conversely, if modelling indicates projects are unable to absorb this added cost without becoming uneconomic (i.e. acceptable 'hurdle rates' are unlikely to be achieved), we can expect a reduction of development activity in selected neighborhoods.

Feasibility modelling for the Sants-Montjuïc and Sant Martí neighborhoods ${ }^{6}$ will seek to capture contextual developmental variations such as achievable rents, land costs, labor costs, among a range of other variables. Modelling efforts will also include a range of common typologies (i.e. development size, scale, unit mix, construction type, market positioning, etc.), which will be based on historical development trends and common typologies pursued by local developers. Modeling will include hypothetical rehabilitation and ground-up development projects. Key inputs will be provided by local developers, other built environment professionals (i.e. architects, engineers, contractors, etc.), city officials and technicians, as well as available market data (market data will be particularly important in setting revenue estimates). Lastly, the feasibility analyses will be tested under a range of market scenarios, illustrating the policy's potential impact on development economics under varying conditions.

In addition to testing the hypothetical projects under a range of market scenarios, the analysis will also test the feasibility impacts of specific policy alterations including:

\footnotetext{
${ }^{6}$ See the previous chapter for the neighborhood selection methodology and results.
} 
- Density bonuses

- Tax incentives

- Waiver of certain development requirements (e.g. open space set-asides)

- Changes in affordability levels

Evaluation of the impacts will be conducted both quantitatively, using feasibility models, as well as qualitatively through interviews with the local development community and city officials. The goal of the qualitative approach is to help determine the policy impacts that are unrelated to economics (i.e. political, social, environmental).

\subsection{Projected Housing Unit Production}

Once the modelling has been completed, using historical development trends (which is briefly illustrated in the previous chapter), unit production projections for each neighborhood or district will be calculated to help 1) determine the efficacy of the proposed inclusionary policy in generating public housing in each neighborhood and 2) predict whether overall supply will be affected to the extent that housing prices are impacted. Such an understanding will allow insight into the extent to which the policy can achieve its intended goals.

\section{Discussion}

The intent of this research is firstly to understand the potential impacts of the proposed inclusionary policy in Barcelona at both the city and neighborhood scale. If the research and modelling envisioned herein reveal that the impacts of the policy appear not to effectively meet the stated policy goals of the City Council, recommended policy changes will be developed and tested.

An effective review of the policy will require an understanding of its potential implications on the Barcelona housing market and the production of public housing, in-depth analyses of both the City Council's economic evaluation of the policy, which is required under Catalan law, and an October $10^{\text {th }}$, 2018 review of the proposed policy by the Col-legi d'Economistes de Catalunya (Romano Córdoba $2018)^{7}$. A thorough comparison of these economic studies will allow for a far more informed feasibility analyses to be conducted.

\section{Conclusions}

Anticipated conclusions of this broader research effort are quantitatively-derived policy recommendations related to the proposed inclusionary housing policy measure. These recommendations will likely relate to how best to calibrate the policy to take into account neighborhood-level market variances, and to better incentivize development activity in order to mitigate any unintended impacts on the broader housing market, such as increasing housing prices due to restricted supply.

\section{Acknowledgments}

I would like to thank my advisor, Dr. Carmen Mendoza Arroyo, for her consistent and thoughtful guidance and support in developing this line of research. I would also like to thank UN-Habitat's City Resilience Profiling Programme for allowing collaboration in pursuing this important topic of housing affordability in Barcelona.

\section{Conflict of Interest}

The author declares no conflict of interest.

\footnotetext{
${ }^{7}$ Documentation of the discussion can be found here: http://www.coleconomistes.cat/Eventos/wf_curso.aspx?IdMenu=a2ef68da-9e11-4618-b4cc30e817f701cd\&Cod=11869\&Idioma $=$ ca-ES
} 


\section{References and Notes}

- Ajuntament de Barcelona. 2017. "Social Rights." Www.barcelona.cat. Available online: http://ajuntament.barcelona.cat/dretssocials/es (accessed on 18 November 2018).

- Ajuntament de Barcelona. 2018. "Servei De Premsa." Ajuntament de Barcelona. Available online: https://ajuntament.barcelona.cat/premsa/2018/09/21/lajuntament-i-la-generalitatacorden-incrementar-les-aportacions-economiques-a-la-ciutat-de-barcelona-en-64-milionsdeuros-per-ampliar-els-pisos-de-lloguer-assequible/ (accessed on 18 November 2018); table can be found here: https://ajuntament.barcelona.cat/premsa/wpcontent/uploads/2018/09/quadre chb.pdf (accessed on 18 November 2018)

- $\quad$ Ajuntament de Barcelona. 2018. "MODIFICACIÓ DEL PLA GENERAL METROPOLITÀ PER L'OBTENCIÓ D'HABITATGE DE PROTECCIÓ PÚBLICA AL SÒL URBÀ CONSOLIDAT DE BARCELONA". Available online:

https://www.arquitectes.cat/ca/system/files/users/14663/20180531b_mpgm_suc_document.pdf (accessed on 18 November 2018).

- Angel, Shlomo and Kallergis, Achilles. 2016. "Global Housing Affordability: What do we know?" Global Housing Watch Newsletter, September 2016. Available online: http://unassumingeconomist.com/wp-content/uploads/2016/09/Global-Housing-WatchNewsletter 09 16.pdf (accessed on 18 November 2018).

- Atkinson, R. 2004. "The evidence of the impact of gentrification: new lessons for urban renaissance? European Journal of Housing Policy, 4(1), 107-131.

- Boston Planning and Development Agency (BPDA). 2015. "The Inclusionary Development Policy." City of Boston, Massachusetts. Available online: http://www.bostonplans.org/getattachment/91c30f77-6836-43f9-85b9-f0ad73df9f7c. Accessed 19 November 2018.

- Calavita, N. \& Mallach, A. 2010. "Inclusionary Housing in the International Perspective: Affordable Housing, Social Inclusion, and Land Value Recapture.” Lincoln Institute of Land Policy. Washington, D.C.

- California Coalition for Rural Housing. 2003."Inclusionary Housing in California: 30 Years of Innovation.” Publication. California Coalition for Rural Housing and Non-Profit Housing Association of Northern California.

- Ellen, I.G. and O'Regan, K. 2008. "Reversal of fortunes? Lower-income urban neighborhoods in the US in the 1990s." Urban Studies 45: 845-869.

- Gabàs, A. 2018. "Barcelona Resilience Department" Presented for United Cities and Local Governments, Barcelona, Spain. Presentation attended by author.

- Hodge, D.C. (1981). Residential revitalization and displacement in a growth region. Geographical Review, 71(2), 188-200.

- Hollingshead, A. 2015. "Do Inclusionary Housing Policies Promote Housing Affordability." Working Paper WP15AH1. University of California, Berkeley

- Hughen, W. Keener, and Dustin C. Read. "Inclusionary Housing Policies, Stigma Effects and Strategic Production Decisions." The Journal of Real Estate Finance and Economics 48, no. 4 (2013): 589-610. doi:10.1007/s11146-013-9402-7.

- Jorro, Ignasi. "Tres Trucos Para Sortear La Tasa Del 30\% De VPO De Colau." Crónica Business. June 22, 2018. Available online: https://cronicaglobal.elespanol.com/business/trucos30-vivienda-social-barcelona-pisos-protegidos_150542_102.html (accessed on 18 November 2018).

- Lazarovic, Rebecca. 2010. A comparison of workforce housing practices in three cities and their applicability to Montreal. Masters thesis, McGill University.

- London City Hall. 2017. "Mayor's New Planning Rules to Boost Affordable Housing." London City Hall. August 16, 2017. Available online: https://www.london.gov.uk/pressreleases/mayoral/sadiqs-new-rules-to-speed-up-planning-in-london. Accessed November 19, 2018. 
- Knaap, G., Bento, A., Lowe, S. 2008. "Housing Market Impacts of Inclusionary Zoning.” National Center for Smart Growth.

- Mallach, A. 2008. "Managing neighborhood change. A framework for sustainable and equitable revitalization." Presented for the National Housing Institute, Montclair, NJ. Available online: from: http://www.mayorsinnovation.org/pdf/ManagingNeighborhoodChange.pdf. Accessed 17 November 2018.

- Monk, S. 2010. "England: Affordable housing through the planning system: the role of Section 106". In N. Calavita \& A. Mallach .2010. "Inclusionary housing in international perspective: Affordable housing, social inclusion, and land value recapture" (pp. 123-168). Cambridge, MA: Lincoln Institute of Land Policy.

- Montaner, Josep, Javier Burrón, and Ángels Cortadellas, et al. 2016. “Qüestions D’Habitatge.” Publication. Barcelona City Council Municipal Housing Board. 2016 ed. Vol. 20. Qüestions D'Habitatge. Barcelona: Directorate of Image and Editorial Services, 2016. Available online: http://www.pmhb.org/repdoc/66994-20161216105251.pdf (accessed 10 October 2018).

- Morrison, Nicky, and Gemma Burgess. 2013. "Inclusionary Housing Policy in England: The Impact of the Downturn on the Delivery of Affordable Housing through Section 106." Journal of Housing and the Built Environment 29, no. 3 (2013): 423-38. doi:10.1007/s10901-013-93607.

- $\quad$ Nadeu, Ferran. "Govern Y Ayuntamiento Aceleran El Plan De Barcelona Para Reservar El 30\% a Vivienda Social." El Periódico. October 19, 2018. Available online: https://www.elperiodico.com/es/barcelona/20181019/reserva-30-pisos-sociales-barcelona7097835 (accessed on 18 November 2018).

- Non-Profit Housing Association of Northern California. 2007. "Affordable by Choice: Trends in California Inclusionary Housing Programs." San Francisco, CA.

- Padilla, Laura. 1995. "Reflections on Inclusionary Housing and a Renewed Look at its Viability." Hofstra Law Review 23 (3), 539-626.

- Pagani, G. 2018."Discussions with Giovanni Pagani Urban Resilience Specialist, City Resilience Profiling Programme, UN-Habitat." Interviews by author. July, September, October, November 2018.

- Pittini, A. and Laino, E. 2011. "The nuts and bolts of European social housing systems." Housing Europe Review 2012. CECODHAS, Brussels.

- Ponce, Juli. "Land Use Law, Liberalization, and Social Cohesion Through Affordable Housing in Europe: The Spanish Case." The Urban Lawyer 36, no. 2 (2004): 317-40. http://www.jstor.org/stable/27895489.

- Romano Córdoba, J. 2018. "Discussion with Joaquim Romano Córdoba, Urban Planner, Institut Catalá del Sól." Interview by author. November 2018.

- Republique Francaise. "De La Loi Solidarité Et Renouvellement Urbain à La Loi Alur." Vie Publique - Au Coeur Du Débat Public. May 21, 2014. Available online: http://www.viepublique.fr/politiques-publiques/logement-social/index/ (accessed on 18 November 2018).

- Rose, Damaris, Annick Germain, Marie-Hélène Bacqué, Gary Bridge, Yankel Fijalkow, and Tom Slater. "'Social Mix' and Neighbourhood Revitalization in a Transatlantic Perspective: Comparing Local Policy Discourses and Expectations in Paris (France), Bristol (UK) and Montréal (Canada)." International Journal of Urban and Regional Research 37, no. 2 (2012): 430-50. doi:10.1111/j.1468-2427.2012.01127.x.

- Schill, M.H. \& Nathan, R.P. 1983. "Revitalizing America's cities: Neighborhood reinvestment and displacement." Albany, NY: SUNY Press.

- Schuetz, Jenny, Rachel Metzler, and Vicki Been. 2009. "Silver Bullet or Trojan Horse? The Effects of Inclusionary Zoning on Local Housing Markets." Urban Studies.

- Schwartz, Heather L., Ecola, Lisa, Leuschner, Kristin J. and Aaron Kofner. 2012. "Is Inclusionary Zoning Inclusionary? A Guide for Practitioners.” RAND Environment, Energy and Economic Development: Santa Monica, California.

- Walks, R. A. and Maaranen, R. 2008. "Neighborhood gentrification". (Doctoral Dissertation). University of Toronto, CAN. 
(C) 2018 by Walker Toma; licensee MDPI and IFoU, This article is an open access article distributed under the terms and conditions of the Creative Commons Attribution license. 